those who have the interests of European collaboration at heart.

There is more scope for experiments in collaboration in fundamental science, though even here scepticism is an asset. 'Thus Mr Patrick Gordon Walker's proposal at the OECD meeting that there should be a European Science Research Council is unlikely to serve a useful purpose. Bodies like this cut very little ice if they lack money and constitutional authority, and there is no sign that Mr Gordon Walker's own department is at this stage prepared to surrender any of its rights to determine how all its money should be spent. There is more virtue in the OECD proposal that there should be a system of matching funds to support scientific research projects in Europe-even though this is beginning on a modest scale there is plainly much that can be done. But where European governments really need to take an energetic interest in European affairs is in the provision of funds for travel between European universities. The schemes already started should grow quickly. It is not too soon to ask what machinery there should be for encouraging the exchange of undergraduates between European universities, for a free exchange must obviously be a part of any integrated technological community. The fact that this is somewhat slow and undramatic work may mean that the politicians are less enlivened than they should be, but is it not wrong of them to think that there are magic wands to make their grand designs come true?

\section{University Candidates}

The fifth report of the Universities Central Council on Admissions, published last week (6s.), offers few words of encouragement for the ever-increasing number of university applicants. In October 1967, of the 101,600 candidates (including 9,600 from overseas) who applied through UCCA for admission to universities in the United Kingdom, only 50,500 (49.7 per cent) were actually accepted. Candidates admitted under other arrangements made outside the UCCA scheme boosted the number to 56,200 .

The report points out that-as in previous yearsthere was a shortage of suitably qualified candidates for places in pure science and technology, and examination qualifications required for admission to these courses were considerably lower than the requirements for other subjects. Only in the biological sciences was the supply of qualified eandidates nearly adequate to fill the number of places. There was a surplus of applicants for the arts and social studies groups, and competition was very keen in accountancy, anthropology, geography, law, polities, psychology and sociology: even candidates with high grades at advanced level found it impossible to find places. English courses were under particular strain, but the burden was eased by accommodating some applicants in a combined course.

A surplus of candidates also tried for places in the medical group of subjects, although there was less competition for dentistry and the medical sciences (physiology and biochemistry) than for the MB ChB course.
By June 1967, 13,700 candidates had been placed, and when the results of the General Certificate of Education, Scottish Certificate of Education and other examinations were published in July and August, a further 32,600 candidates were accepted. Of the remainder, 20,489 candidates applied for consideration in the clearing operation which began on September 1 . As a result, a further 4,200 were placed.

The UCCA admissions scheme has now been operating for six years under the chairmanship of Dr G. Templeman, vice-chancellor of the University of Kent. Except for a small number of Scottish candidates who apply directly to one of the three universities of Edinburgh, Dundee and Aberdeen, all other candidates including those for Oxford and Cambridge apply through UCCA. UCCA's co-ordinating role is there fore a very large one: between October 1966 and January 1967 it produced and distributed nearly 600,000 copies of application forms to the universities. Between the time these were received and final decisions were despatched to candidates, some two million individual transactions were conducted through UCCA.

In 1967, for the first time, UCCA rented its own computer, and this has enabled a larger volume of work to be handled with fewer delays. Looking to the future, the report hopes that education boards which use computers will be able to transmit results of Advanced level examinations directly to universities by computer tape or computer-printed lists, in a form that corresponds with the way universities keep their records of UCCA applications. This will mean that candidates will require reference numbers, and a network of com-

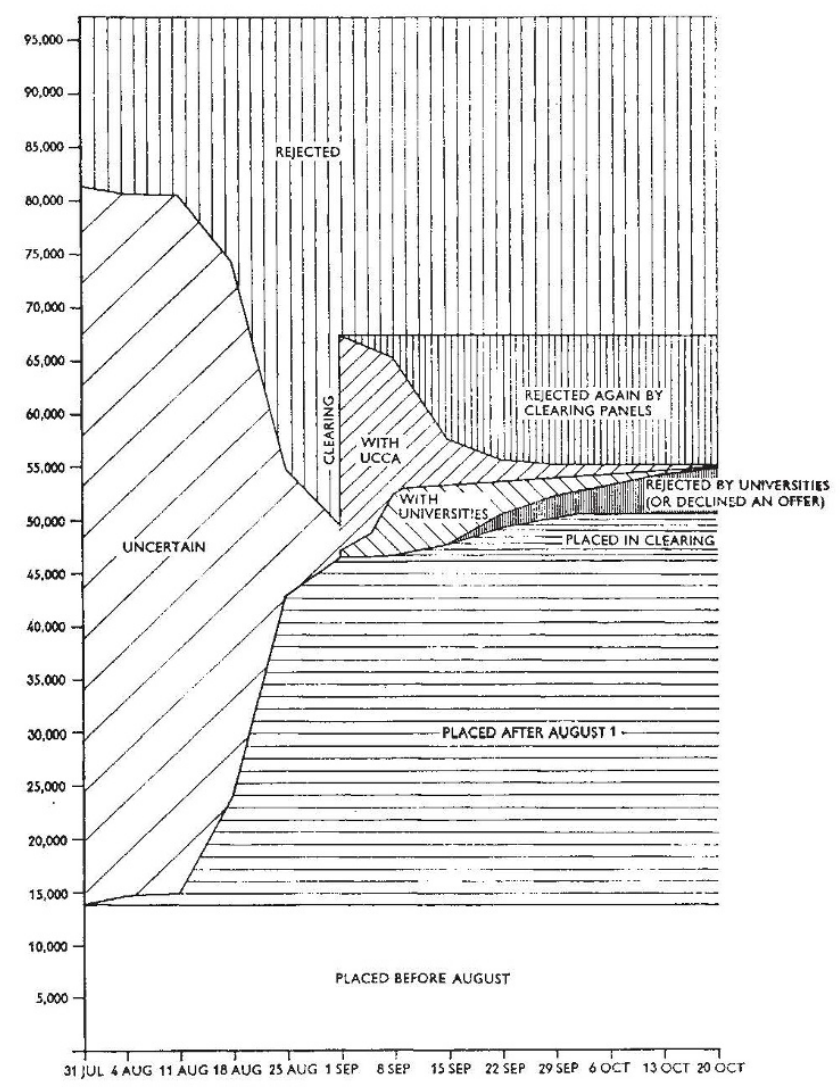

Acceptances and rejections during conformation and clearing, August I to October 20, 1967. 
puterized communications will have to be developed between UCCA, the examining boards and the universities.

Another scheme for assisting and quickening the selection procedure is the use of an aptitude test. Together with the opinion of a head teacher and a university interview, this would provide a valuable assessment of a candidate's ability and suitability. A pilot scheme along these lines is now being carried out by the Committee of Vice-Chancellors and Principals of the United Kingdom, with the co-operation of the central council.

\begin{tabular}{|c|c|c|}
\hline \multirow[t]{2}{*}{ Subject } & \multicolumn{2}{|c|}{$\begin{array}{l}\text { Total candidates through } \\
\text { UCCA, October } 1966 \text {, by } \\
\text { order of first preference : }\end{array}$} \\
\hline & Applied & Accepted \\
\hline Education & 654 & 148 \\
\hline $\begin{array}{l}\text { Medicine, dentistry and } \\
\text { health }\end{array}$ & 8,255 & 2,434 \\
\hline Engineering and technology & 13,686 & 7,677 \\
\hline $\begin{array}{l}\text { Agriculture, forestry, } \\
\text { veterinary science }\end{array}$ & 1,975 & 896 \\
\hline Pure science & 18,306 & 12,850 \\
\hline $\begin{array}{l}\text { Social, administrative, } \\
\text { business studies }\end{array}$ & 24,882 & 9,533 \\
\hline $\begin{array}{l}\text { Architecture, and other } \\
\text { professional and vocational } \\
\text { subjects }\end{array}$ & 2,049 & 485 \\
\hline $\begin{array}{l}\text { Language, literature, area } \\
\text { studies }\end{array}$ & 13,181 & $6, \tilde{5} 09$ \\
\hline Arts other than languages & 7,633 & 3,986 \\
\hline Total & 90,952 & 44,526 \\
\hline
\end{tabular}

\section{UNCTAD in Tatters}

Tre second United Nations Conference on Tariffs and Trade, just completed in New Delhi, was heralded with such gloomy predictions that little was expected of it. In the event, even less seems to have been achieved. The conference ended with the admission that little had been done to bridgo the widening gap between rich and poor. Some last minute sessions did manage to salvage something from the ruins, in the form of several agreed statements, but these are so feebly expressed and hedged about with conditions as to make them nearly useless. There now seems to be a real danger that the underdeveloped countries will decide to wash their hands of the West, and may even perhaps go as far as to cancel their debts and decide that they can do better on their own.

The fundamental problem seems to have been that the Western countries had nothing to offer. Under the pressure of unfavourable external balance of payments and a disenchantment with aid, the United States, Britain and France have all reduced their aid this year. (Aid from Britain, though constant in sterling terms, will fall because of devaluation.) In this situation, it was impossible that the demands of the developing countries could be met, although the president of UNCTAD, Dinesh Singh, did have a good word to say for the socialist countries of Eastern Europe.

Two things were decided at New Delhi. First, after a lengthy discussion, it was agreed in principle that the aid given by developed countries should represent one per cent of their gross national products. The alternative, based on one per cent of the national income, is a lower target. So the final decision does set slightly higher targets, although it sets no date for these to be reached. France favoured the change to the new target, in part, it seems, because its own aid is more generous than other countries, and it finds more ambitious standards less embarrassing than other countries do.

The conference also agreed in principle to give preferences to manufactured products from developing countries. But the agreement excludes manufactured agricultural products, and the United States also wishes to exclude textiles from the agreement. The United States also made agreement conditional on French agreement to give up its existing preferences with developing countries. The idea of supplementary financing, to help countries whose external balances are hit by the fluctuating prices for commodities, seems to have survived the conference, but not to have made much progress. The scheme, originally put forward by the UK and Sweden at the first UNCTAD meeting, was opposed by France. The communiqué says little on the subject, but does agree to keep in being the inter-governmental group which is studying the problem.

The secretary-general of UNCTAD, Dr Raul Prebisch, now hopes that a ministerial meeting on aid will be held in 1969. By that time, perhaps, the climate could be more favourable. But Dr Prebisch will be very lucky if he can recoup in 1969 the loss of goodwill which seems to have been suffered at New Delhi. The British position will at best be only on the mend, and the United States is unlikely by then to have repaired entirely its balance of payments deficit.

\section{Inadequate Training}

SOME rather startling criticisms of teacher-training courses for chemistry graduates appear in a recent publication compiled by the British Committee on Chemical Education, sponsored jointly by the Royal Society and the Royal Institute of Chemistry (price $3 s .6 d$.). It brings out that there is not only a marked difference between the recognized priorities and needs of the teachers and the actual courses and facilities provided for them, but that topics relating to the teaching of chemistry are not adequately studied either in education institutions or during teaching practice.

These criticisms are drawn from replies to questionnaires sent out by the committee with the aim of obtaining from university departments of education and colleges of education in the United Kingdom information about their courses and training. A second aim was to obtain from practising graduate teachers of chemistry their opinion of the type of teacher-training studies that would be most useful to them.

The last time an inquiry of this sort was carried out was in 1959 when the Association for Science Education appointed a subcommittee of practising school teachers, lecturers in university departments of education, and lecturers in colleges of education to investigate the training of science teachers. At the time it was concluded that the facilities, both in time and in accom. modation for practical work, were quite inadequate. A number of the issues which emerged during the association's inquiry emerged again in the recent study. Out of 130 replies from experienced teachers in 